\title{
SOME POPULATION PARAMETERS OF ENDEAVOUR SHRIMP (Metapenaeus ensis de Haan) IN BALIKPAPAN SURROUNDING WATERS, EAST KALIMANTAN
}

\author{
Ali Suman'1) and Gatut Bintoro²) \\ Researcher at Research Institute for Inland Fisheries-Mariana, Palembang \\ 2) Researcher at Pangkep State Agriculture Polytechnic, South Sulawesi \\ Received May 22-2009; Received in revised form August 28-2009; Accepted November 20-2009
}

\begin{abstract}
Study on the population parameters of endeavour shrimp (Metapenaeus ensis de Haan) was conducted in Balikpapan waters, East Kalimantan. Population parameters of the endeavour shrimp were calculated based on data collected during period of survey, March 2006-November 2006. Result showed that the growth parameter $(K)$ of endeavour shrimp was 1.6/year with maximum carapace length $\left(L_{n}\right)$ of $42.0 \mathrm{~mm}$. Instantaneous total mortality $(Z)$, natural mortality $(M)$, and fishing mortality $(F)$ were 4.52/year, 2.18/year, and 2.34/year, respectively. The exploitation rate (E) was estimated to be $0.52 /$ year which indicated that the status of endeavour shrimp stock in Balikpapan surrounding waters was categorized as fully exploited. It is, therefore, recommended that additional amount of fishing effort of the endeavour shrimp in this area should be stopped in the next year.
\end{abstract}

KEYWORDS: population parameters, endeavour shrimp, Balikpapan waters

\section{INTRODUCTION}

Endeavour shrimp (Metapenaeus ensis de Haan) which has local name "udang dogol" is one of important economic shrimp resources in Balikpapan surrounding waters. In this area, catch landed of this shrimp species was about $25 \%$ of total penaeid shrimp yearly production (Suman et al., 2006). This shrimp resource has been exploited since long time ago. Yet commercial fishing activity toward the resource has only been started since 1960 due to the present of trawl fishery development in this area. Since that period, fishing acti ity of the shrimp has been intensively developed and increased from year to year due to increasing number of fishing effort and the fishermen (Naamin, 1978).

Shrimp resource is categorized as renewable resources, but intensively fishing activity year by year will deplete the resource. As it has occurred toward the shrimp resource in Balikpapan surrounding waters, this condition would threat sustainability of the stock as a result depletion of the stock will come soon. Naamin (1984) stated that increasing fishing effort to certain level can increase the catch. After certain level of the catch is reached, called maximum sustainable yield, the catch will decrease even though the effort is increased. Cunningham et al. (1985); Withmarsh (1990) added that the more the effort increased, the more the resources were being exploited. Meanwhile the resources themselves had maximum capability to the long run of yield. Hence the catch ability coefficient would rise until maximum sustainable yield was reached, but as fishing was further intensified (increase in effort), the productivity would be decline. Therefore, exploitation of the shrimp resource should be managed and tishing effort should be regulated properly in order to enhance the stock sustainability.

The shrimp stock and fishing activity in Balikpapan surrounding waters should be managed properly to give chance the stocks to recover themselves so that sustainability of the stocks can be kept in the future. Some research toward the shrimp stock status need to be done in order to obtain scientific data for management purpose. This report discusses some population parameters of the endeavour shrimp stock in Balikpapan surrounding waters. It hopes that these data can be used for future stock identification and management purpose.

\section{MATERIALS AND METHODS}

Samples of the endeavour shrimp were taken from field research in Balikpapan and surrounding waters (Figure 1) conducted from March 2006-November 2006. Biometric studies (carapace length, sex, and gonad maturity identifications) were taken from 1,600 samples. Growth rate $(\mathrm{K})$ and maximum carapace length $(\mathrm{L}$ ) were analyzed by tracing modus of monthly carapace length distribution using ELEFAN program (Sparre \& Venema, 1992; Gayanilo et al., 1993). Total mortality (Z) was calculated from catch curve (Sparre \& Venema, 1992; Gayanilo et al., 1993) and natural mortality (M) was predicted using combination of Pauly empiric equation (Pauly, 1985) and fishing mortality rate $(F)=Z-M$, where exploitation rate $(E)=F / Z$ (Sparre \& Venema, 1992). 


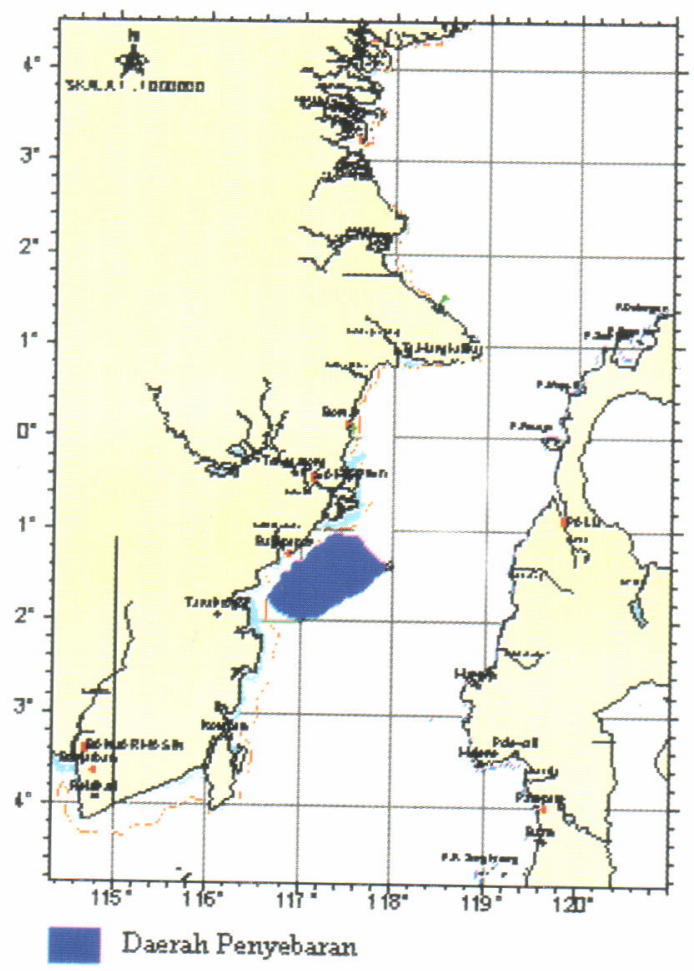

Figure 1. Fishing ground of endeavour shrimp in Balikpapan surrounding waters.

\section{RESULTS AND DISCUSSIONS}

\section{General Condition of Shrimp Fisheries}

In general, there are 9 species of shrimps caught in Balikpapan and surrounding waters. They are divided into three groups, namely white shrimp (Penaeus merguiensis), endeavour shrimp (Metapenaeus ensis), and others (Metapenaeus lysianassa, $M$. brevicornis, $M$. dobsoni, Parapenaeopsis stylifera, Parapenaeopsis sp., Solenocera subnuda, and Palaemon sp.). In the last 10 years, beside these three groups, tiger prawn (udang windu) also occurred in Balikpapan surrounding waters and together with white shrimp, the catch of this species dominated shrimp landed (Figure 2).

Since restriction of trawl to be operated in Balikpapan and surrounding waters, dogol and trammel net have become dominant fishing gears operated in this area. Jaring dogol (fishermen call this gear as belly net) was first introduced in 1981 and adopted from fishermen of north coast of Java Sea waters (Suman et al., 2006). Trammel net is usually categorized as bottom gillnet (Nomura, 1974); Brandt (1972) classified this into entangled net. This gear consists of three pieces of net (triple walled net), namely outer net (2 pieces) and inner net (1 piece). Both outer nets have mesh size much higher than that of the inner net. This specific construction leads to the shrimp which enters the outer nets will be entangled in the outer nets and walleyed in inner net. In Japan, this gear is actually and effectively used to catch fish (Matuda \& Kitahara, 1967). However in Indonesia, with several modifications in size and material, trammel net can be applied to catch shrimp (Wudianto et al., 1988). In Balikpapan surrounding waters, the trammel net is operated in one way method by sweeping the net in the bottom of the waters, as an active fishing gear.

Sea survey in Balikpapan surrounding waters showed that fishing rate of the shrimp varied from 0.14 $2.22 \mathrm{~kg} / \mathrm{hauling}$ and its stock density was $28.5 \mathrm{~kg} /$ $\mathrm{km}^{2}$ (Suman et al., 2006). Fishing ground of the shrimp was stretched from Samboja estuarine in the east part to Penajam waters in the west with the depth of 5-40 m (Figure 1). While fishing season occurred during entire year and peak seasons happened twice a year in May and September.

\section{Population Parameters}

Basically ELEFAN program is applied to interpret carapace length frequency data by tracing the movement of carapace length time series data plotted to von Bertalanffy curve. Line which passes through the highest amount of modus will illustrate the growth curve (Sparre \& Venema, 1992). 
By tracing monthly data of carapace length frequency, growth rate $(K)$ of the endeavour shrimp in Balikpapan surrounding waters was predicted to be 1.6 per year (Figure 3 ) with the maximum carapace length $\left(L_{n}\right)$ was $42.0 \mathrm{~mm}$. Therefore, von Bertalanffy growth equation was ilustrated as $\mathrm{Lt}=42.0$ $\left[1-e^{-1,6(t-0)}\right]$.

Value $\mathrm{K}$ of the shrimp was higher than 1 which indicated that the shrimp was categorized as fast growth species (Gulland, 1983; Naamin, 1984). The faster the growth rate and the shorter the age of shrimp illustrated that fishing mortality rate of the shrimp was high. This condition informed that more attention should be paid to the sustainable utilization of the stock. Carefully assessment on correct time to exploit the stock should be based on sustainability of the stock and economic point of view. If the shrimps are caught too late, they will die useless. Yet benefit will not be obtained optimally when the stock is exploited too early.

Based on growth parameter obtained where $\mathrm{K}=1.6$ and $L_{n}=42.0 \mathrm{~mm}$, catch curve can be drawn. Mortality rate $(Z)$ prediction would be 4.52 per year (Figure 4 ).

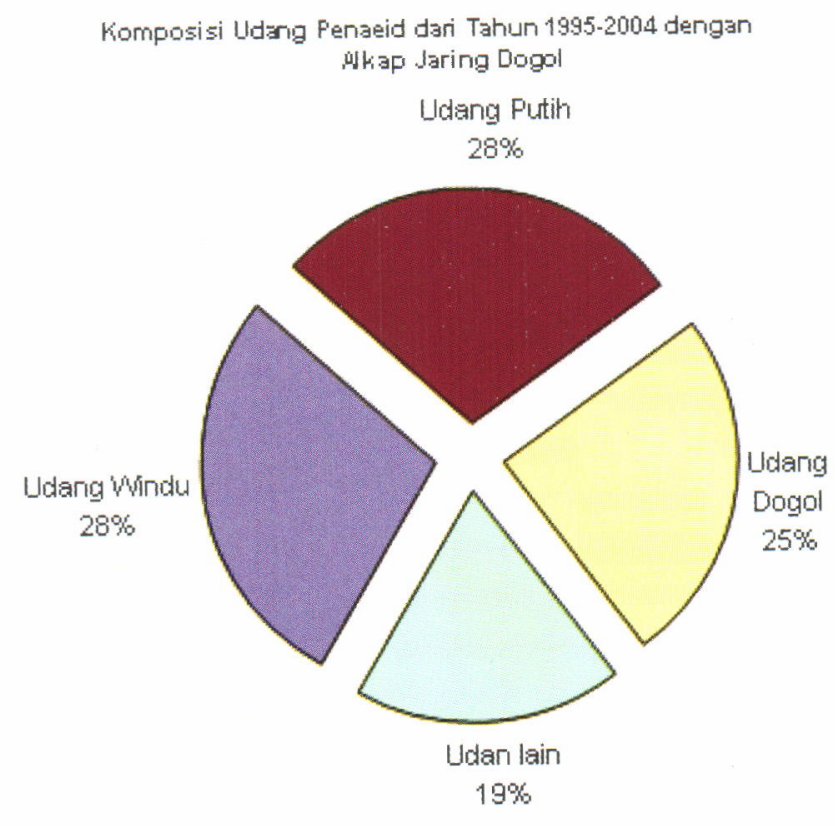

Figure 2. Shrimp landed composition (1995-2004) caught by Dogol in Balikpapan surrounding waters.

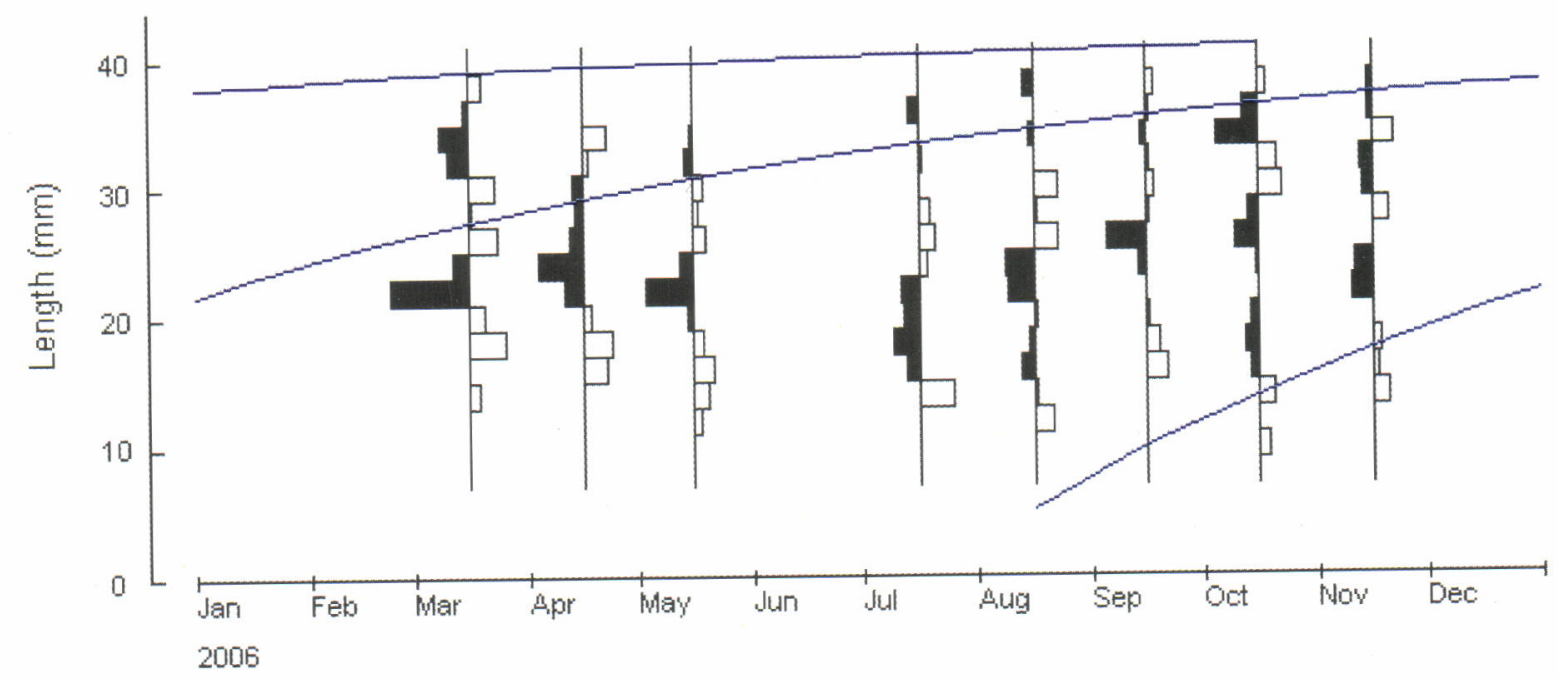

Figure 3. Monthly data of carapace length frequency distribution of endeavour shrimp ( $M$. ensis) analysed by ELEFAN method in Balikpapan surrounding waters. 


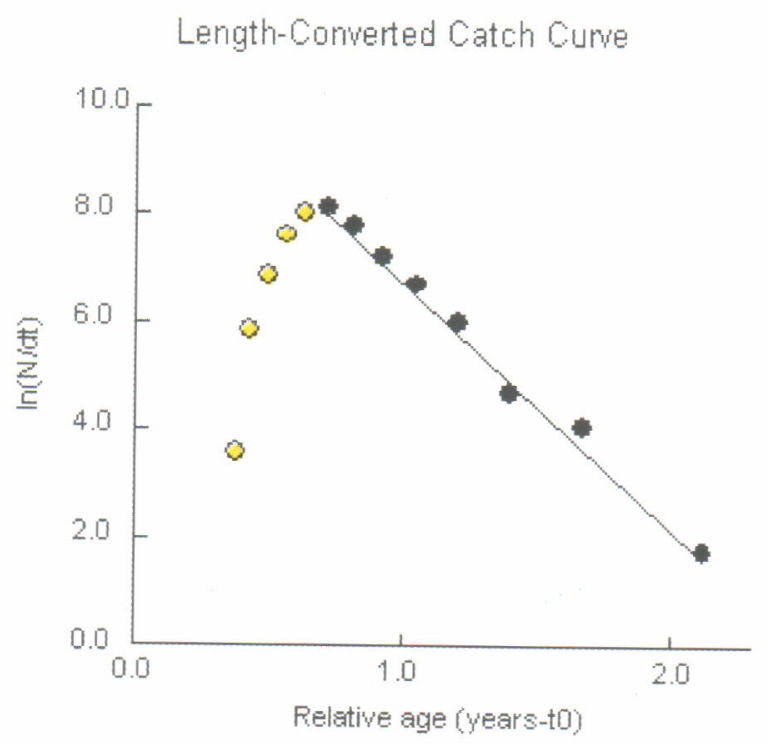

Figure 4. Value of $Z$ as the slope of the endeavour shrimp (M. ensis de Haan) in Balikpapan surrounding waters.

While natural mortality $(\mathrm{M})$ and fishing mortality $(\mathrm{F})$ rates calculated by Pauly (1980) were about 2.18 and 2.34 respectively.

Pauly et al. (1984) reported that value of $Z$ and $F$ of Indian shrimp in Versoba waters, respectively were 5.29 year and 3.0/year. While value of $Z$ and $F$ of Metapenaeus kutchensis were 5.83/year and 2.20/ year, respectively. It was presented that difference in value of shrimp mortality rates in several waters were caused by different level of effort number, predator, and environment condition.

Using exploitation rate equation $(E)=F / Z$, it was obtained that $E$ of endeavour shrimp in Balikpapan surrounding waters was 0.52 /year. Based on Pauly criterion (Pauly et al., 1984), it was concluded that fully exploited of the shrimp stock has occurred in Balikpapan surrounding waters because rational fishing of fish or shrimp stock can be gained if values of $E$ in that waters equals to 0.5 . If value of $E$ is more than 0.5 , the stock will be threatened thus effort has to be decreased in order to sustain the stock.

\section{CONCLUSSIONS}

1. Values of growth rate $(\mathrm{K})$ and maximum carapace length ( $\left.L_{\text {.. }}\right)$ of the endeavour shrimp (M. ensis) in Balikpapan and surrounding waters were 1.6/year and $42.0 \mathrm{~mm}$, respectively.

2. Values of total mortality (Z), natural mortality (M), and fishing mortality $(F)$ of the endeavour shrimp ( $M$. ensis) were 4.52/year, 2.18/year, and 2.34/ year, respectively.
3. Carefully utilization of the endeavour shrimp ( $M$. ensis de Haan) in Balikpapan surrounding waters should be applied in order to maintain stock sustainability in the future due to high growth and mortality rates of the stock.

4. The endeavour shrimp stock in Balikpapan surrounding waters was categorized as fully exploited $(E=0.52)$ so that the additional amount of fishing unit in this area should be stopped.

\section{ACKNOWLEDGEMENT}

This paper was part of inhouse program titled riset stock assessment, life history, and population dynamic of resources demersal fish and penaeid shrimp in South China Sea, Java Sea, and Makassar Strait, F.Y. 2006.

\section{REFERENCES}

Brandt, A. V. 1972. Fish Catching Methods of the World. Fishing News Books Ltd. 110 Fleet Street. London. EC 4. 204-214.

Cunningham, S., M. R. Dunn, \& D. Withmarsh. 1985. Fisheries Economics: an Introduction. Mansell Publishing Ltd. London. 372 pp.

Gayanilo, F. C. Jr, P. Sparre, \& D. Pauly. 1993. The FISAT user's guide. FAO Computerized Information Series Fisheries. ICLARM-DIFMAR. 
Gulland, J.A. 1983. Fish stock assessment. A Manual of Basic Methods. John Wiley \& Sons. Chicester. $233 \mathrm{pp}$.

Matuda, K. \& T. Kitahara. 1967. On the estimation of catching efficiency of sweeping trammel net. Bulletin of Japanese Society of Scientific Fisheries. 33. (12): 1,096-1,098.

Naamin, N. 1978. Development of shrimp fishery in Cilacap and Pangandaran waters. Journal of Capture Fisheries Research. 1: 59-79

Naamin, N. 1984. Population dynamic of jerbung shrimp (Penaeus merguiensis de Man) fishery in Arafuru waters and its utilization alternative. Doctor Dissertation in Post Graduate Faculty. Bogor Agricultural University. Bogor. 381 pp. Unpublished.

Nomura, M. 1974. Gillnet fishery, Japanese fishing gear, and methods. Texbook for Marine Fisheries Research Course. OTCA. Goverment of Japan. 103-130.

Pauly, D. 1980. A selection of a simple method for the assessment of tropical fish stocks. FAO Fish. Circ. FIRM/C 729. Roma. 54 pp.

Pauly, D., J. Ingles, \& R. Neal. 1984. Application to shrimp stocks of objective methods for the estimation of growth, mortality, and recruitment related parameters from length frequency data (ELEFANI and II). In Penaeid Shrimp-Their Biology and Management. Fishing News Book Limited. Farnham-Surrey-England. 220-234.

Pauly, D. 1985. Some simple method for the assessment fish stock. FAO Fish. Tech. Paper (234). Rome.

Sparre, P. \& S. C. Venema. 1992. Introduction to tropical fish stock assessment. Part I Manual. FAO Fish. Tech Pap. No.306/1.

Suman, A., Badrudin, S. T. Hartati, B. Sumiono, I. S. Wahyuni, \& T. Ernawati. 2006. Stock assessment, life history, and population dynamic of demersal fish and penaeid shrimp in South Cina Sea, Java Sea, and Makassar Strait. Yearly Report. Research Institute for Marine Fisheries-Research Center for Capture Fisheries-Agency for Marine and Fisheries Research. Jakarta.

Wudianto, A. Anung, \& Ch. Nasution. 1988. Effect of The use of mono and multifilament as material of trammel net based on location toward catch of banana prawn (Penaeus merguiensis). Journal of Capture Fisheries Research. 48: 83-91. 
